\title{
Arafta Bir Yaşam: Kemik Illiği Nakli Olan Bir Çocuğun Annesi Olmak
}

\section{A Life in Purgatory: Being the Mother of a Bone Marrow Transplant Child}

\author{
Esra Engin' (D), Mahire Olcay Çam' (D), Hacer Demirkol' (D)
}

\begin{abstract}
$\ddot{0} z$
Kemik iliği nakli çocuklarda başlıca hematolojik malignansi, immun yetmezlik ve kemik iliği yetmezliği gibi morbidite ve mortalite oranı oldukça yüksek hastalıklarda kullanılan bir tedavi yöntemidir. Kemik iliği nakli bu hastalıkların tedavisinde başarı şansını artırmasına ve yaşam süresini uzatmasına karşın, bazı sistemik komplikasyonları da beraberinde getirmektedir. Çocuk için oldukça zor olan bu süreçte en çok etkilenen aile bireyinin ise genellikle anne olduğu bildirilmektedir. Uzun süre özenli bakım verme annede bakım yükü oluşturmaktadır. Ayrıca nakilin başarılı olup olmayacağı, hastalığın tekrarlaması, çocuğu kaybetme, kayıptan sonra yaşamın nasıl devam edeceği gibi düşünceler annede belirsizliğe, ayrlık anksiyetesine ve varoluşsal kaygılara neden olmaktadır. Çocuğu kemik iliği nakli olan annelerde depresyon, anksiyete bozukluğu ve post travmatik stres bozukluğu gibi psikiyatrik bozuklukların oldukça sık görüldüğü bildirilmektedir. Hem çocuk hem de anne için travmatik olan bu süreçte primer tedavi ekibi ile birlikte Konsültasyon Liyezon Psikiyatrisi (KLP) hemşiresinin rolü önemlidir. Bu sebeple bu derleme, çocuğu kemik iliği nakli olmuş annelerin deneyimlerini, yaşadığı çok boyutlu sorunlarını açıklamak ve bu süreçte KLP hemşiresinin rolünü tanımlamak amacılyla yazıımıştır.
\end{abstract}

Anahtar sözcükler: Kemik iliği nakli, çocuk, anne, psikiyatri hemşiresi, konsültasyon liyezon psikiyatrisi hemşireliği

\section{Abstract}

Bone marrow transplantation is a therapy used for children who have certain diseases with high rates of morbidity and mortality as hematologic malignancies, immune deficiency and bone marrow failure. Bone marrow transplantation increase the chances of success in the treatment of this diseases and prolongs lifespan of children, it may also cause some systemic complications as well. During this rather difficult process, particularly for children, it is reported that among the family members, it is often the mother who is affected the most. Long-term attentive care creates a great burden for the mother. Moreover, concerns about whether transplantation will be successful or not, recurrence of the disease, loss of child, how life will continue after loss cause uncertainty, resulting in separation anxiety and existential anxiety for the mother. It is reported that mental illnesses such as depression, anxiety disorder and post traumatic stress disorder are common among those mothers whose children underwent bone marrow transplantations. In this process, which is traumatic for both the child and the mother, the role of the consultant liaison psychiatry (CLP) nurse together with the primary treatment team is important. Therefore, this review was written to explain the experiences, multidimensional problems of mothers whose children underwent bone marrow transplantation and to describe the role of the consultant liaison psychiatry nurse in this process.

Keywords: Bone marrow transplantation, child; mother, psychiatric nurse, consultation liaison psychiatry nursing

'Ege Üniversitesi, İmir, Türkiye

${ }^{2}$ Yozgat Bozok Üniversitesi, Yozgat, Türkiye

$凶$ Hacer Demirkol, Yozgat Bozok Üniversitesi Sağlık Bilimleri Fakültesi Ruh Sağlğı̆ ve Hastalıkları Anabilim Dalı,Yozgat, Turkey hacer-demirkol@outlook.com | 0000-0002-8639-8376

Geliş tarihi/Received: 26.08.2020 | Kabul tarihi/Accepted: 27.10.2020| Çevrimiçi yayı/Published online: 15.12.2020 
TIPTA 1960’lı yıllar itibariyle yerini almaya başlayan kemik iliği nakli, çocuklarda başlıca hematolojik malignansi, immun yetmezlik, hemoglobinopati, kemik iliği yetmezliği gibi morbidite ve mortalite oranı oldukça yüksek hastalıklarda kullanılmaktadır (Önen 2014, Yeşilipek 2014). Kemik iliği nakli, çocuklarda tıbbi tedavinin başarı şansını artırması ve yaşam süresini uzatmasına karşın, bazı sistemik komplikasyonları beraberinde getirmektedir (Peykerli 2003, Koca ve Akpek 2006, Packman ve ark. 2010, Tanzi 2011). Hazırlama rejiminde ve kemik iliği nakil sürecinde yüksek dozda kemoterapi ve immunsupresiflerin kullanılması; çocukta mukozit, kilo kaybı ya da alımı, enfeksiyon, bulantı, kusma, diyare, ağrı, pulmoner ödem, hemorajik sistit gibi bazı fiziksel komplikasyonların görülmesine neden olmaktadır. Ayrıca allojenik kemik iliği nakli sonrasında immünolojik reaksiyon olarak oluşan graft versus host hastalığ1 (GVHD), yaşamı tehdit eden önemli bir fiziksel komplikasyondur (Manne ve ark. 2001, Koca ve Akpek 2006, Tanzi 2011, Y1lmaz ve ark. 2013, Yeşilipek 2014).

Kemik iliği nakli sonrası çocukta meydana gelen fiziksel komplikasyonlar, uzun süre başkasına bağımlı olma, enfeksiyon riski nedeniyle sosyal izolasyon, yalnızlık, hastalığın tekrarlama korkusu gibi etmenler çocuğun ruhsal sağlığını olumsuz etkilemektedir. Yapılan bazı araştırmalarda, kemik iliği nakli olan çocuklarda genel anksiyete bozukluğu, depresyon, hiperaktivite ve dikkat eksikliği, spesifik fobi, sosyal fobi, enürezis nokturna, enkoprezis, post travmatik stres bozukluğu gibi psikiyatrik hastalıkların görülebildiği bildirilmektedir (Packman ve ark. 2010, Taşkıran ve ark. 2016, Adanır ve ark. 2017).

Çocuğa kanser gibi yaşamı tehdit eden bir hastalık tanısının koyulması ve ardından riskli bir tedavi yöntemi olan kemik iliği naklinin gerçekleştirilmesi, hem çocuk hem de ailesi için travmatik bir deneyimdir. Çocuğun hastalık sürecinde en çok etkilenen aile bireyinin ise genellikle anne olduğu bildirilmektedir (Packman ve ark. 2010, Taşkıran ve ark. 2016, Baran 2018).

Çoğu kadın annelikle beraber çocuğu ile özdeşleşmekte ve onu kendi varlığının bir uzantısı olarak görmeye başlamaktadır (Er 2006). Freud sonrası psikanaliz kuramcılarından Jacques Lacan bu özdeşleşmeyi iğdiş kompleksine bağlamıştır. Ona göre anne iğdiş kompleksini, çocuğunu bilinçdışı olarak kendi fallusu yani kendi parçası kabul ederek yenebilmektedir (Tura 2005). Varoluşçu yaklaşım ise, annenin çocukla özdeşleşmesini yaratıcılık ve hayata anlam katma bağlamında ele almaktadır. Yaratıcılık ve bereket anlamına gelen doğurganlık, hayata anlam katmanın köklü bir yoludur. Anne çocuk doğurarak soyunu yani kendi varlığını devam ettirmeye çabalamaktadır. Hatta anne dünya ya getirdiği çocuğu "kendi benliğinden daha büyük bir şeye sahip olma” şeklinde de yorumlayabilmektedir. Bu durumda anne bu büyük varlığı yani çocuğunu, korumak ve hayattaki devamlılı̆̆ını sağlamak için büyük bir sorumluluk hissetmektedir (Prinds ve ark. 2018, Korucu 2019). Bu artan sorumluluk anne ile çocuğun duyguları arasında geçirgen bir sınır oluşturabilir. Bu durum ise bazı annelerin çocuklarının deneyimlerini kendi deneyimleri gibi algılamalarına neden olmaktadır. Örneğin bu anneler çocuğun bedenine yapılan herhangi bir tıbbi müdahalede çok yoğun bir stres yaşayabilmektedir (Er 2006). Tüm bu açıklamalara ek olarak kemik iliği nakli sürecinde çocuğun annenin sevgisine ve ilgisine ihtiyaç duyması, enfeksiyon kontrolü, kültürel annelik 
rolü gibi etmenler, annenin bakımı tek başına üstlenmesine ve dolayısıyla en çok etkilenen aile bireyi olmasına neden olmaktadır (Manne ve ark. 2001, Er 2006, Ersoy 2009, Y1lmaz ve ark. 2013).

Literatür incelendiğinde, çocuğu kemik iliği nakli olan annelerin yaşadığı sorunların genellikle psikiyatrik bozukluklar ekseninde ele alındığg görülmektedir (Manne ve ark. 2001, Nelson ve ark. 2003, Manne ve ark. 2004, Phipps ve ark. 2004, Vrijomoet-Wiersma ve ark. 2009, Barrera ve Antenafu 2012, Virtue ve ark. 2014, Taşkıran ve ark. 2016). Çocuğun kemik iliği nakil sürecinde annelerin öznel deneyimlerine odaklanan ve annelerle derinlemesine görüşmelerin yapıldığı araştırma sayısı oldukça sınırlıdır (Oppenheim ve ark. 2002, Forinder 2004, Matteo ve Ceron 2015, Asadi ve ark. 2011). Bu derleme çocuğu kemik iliği nakli olan annelerin yaşadığı/yaşayabileceği sorunları gözden geçirmek ve KLP hemşiresinin bu süreçteki rollerine değinmek amacıyla yazılmıştır. Ek olarak derleme yazarlarının çocuğu kemik iliği nakli olan annelerin bakım yükünü azaltmak amacıyla yürüttükleri bir araştırma projeleri bulunmaktadır (Engin ve ark. 2019). Literatürde katkı sağlamak amacıyla, bu projeye katılan annelerin öznel ifadelerine yazılı onamları alınarak derlemede yer verilmiştir.

\section{Annenin çocuğun kemik iliği nakil sürecinde yaşadığı sorunlar}

Çocuğun kanser gibi ciddi bir hastalık tanısı alması genellikle annenin güvenli dünya inancına zarar vererek umutsuzluk yaşamasına neden olmaktadır. Bir tedavi seçeneği olarak kemik iliği naklinin sunulması ise anne için büyük bir umut kaynağıdır. Ancak zaman zaman ölümle sonuçlanabilen ve önemli yan etkileri bulunan kemik iliği nakline karar vermek ebeveynler için oldukça zordur. Çünkü kemik iliği nakli sadece bir başlangıcı temsil etmektedir. Tedavinin nihai hedef olan çocuğun yaşamının devamlılığı kimse tarafindan tam olarak öngörülememektedir (Matteo ve Ceron 2015). Forinder’ in (2004) yaptığı araştırmada bir ebeveyn kemik iliği naklini, "Denize düşen yılana sarılır" sözü ile tanımlamıştır (Forinder 2004). Kısaca kemik iliği nakli sürecinde anne, çocuğunun iyileşmesi (cennet) ve çocuğunu kaybetme (cehennem) düşüncelerinin tam ortasında "arafta” bir yaşam sürmektedir.

Çocuğun kemik iliği nakil süreci anne için oldukça zor bir deneyimdir. Çoğu zaman anne, nakil olan çocuğunun bakımını tek başına yürütmektedir (Manne ve ark. 2001, Er 2006, Ersoy 2009, Y1lmaz ve ark. 2013). Bakım verme, tek bir yardım biçimi olmayıp, fizikselemosyonel-sosyal yardımı kapsayan çok boyutlu bir süreçtir (Açar 2018). Anne kemik iliği nakil sürecinde, hastalık ve hastaneye uyum, mukozit ve kateter bakımı, enfeksiyon kontrolü, kişisel bakım gibi çocuğun birçok gereksinimini yerine getirmektedir (Manne ve ark. 2001, Forinder 2004, Yılmaz ve ark. 2013). Annenin verdiği bakım sadece hastane ile sınırlı kalmayıp taburculuk sonrası da devam etmektedir. Çünkü çocuk nakilden sonra, özellikle ilk altı ay içerisinde, enfeksiyon riski taşımakta ve geç dönem fiziksel komplikasyonlar (GVHD vb.) yaşayabilmektedir (Y1lmaz ve ark. 2013).

Enfeksiyon, kemik iliği nakil sürecinde çocuklarda görülen en önemli mortalite nedenlerinden biridir. Bu sebeple anne, kemik iliği nakli sonrasında da çocuğuna özenle bakım vermeyi sürdürmektedir (Y1lmaz ve ark. 2013, Yeşilipek 2014). Yabroff ve Kim (2009), lenfoma gibi hastalıklara sahip bireylere bakım verenlerin, günde 10 saatten daha 
fazla süreyi sadece bakım için ayırdıklarını bildirmiştir (Yabroff ve Kim 2009). Bakım verilen bireyin çocuk olduğu ve kemik iliği naklinin özel bakım gerektiren bir süreç olduğu düşünüldüğünde ise, annenin tüm yaşamını kemik iliği nakli olan çocuğunun bakımına adadığını söylemek yanlış olmayacaktır.

Anne kemik iliği nakil sürecinde hasta çocuğuna bakım vermenin yanı sıra, donör olan kardeşin ya da diğer çocukların bakımı (bazen diğer çocuklar ebeveynleri tarafından ihmal edilebilmektedir), aile düzenin devam ettirilmesi, işe gitme gibi diğer sorumluluklarını da yerine getirmeye çalışmaktadır. Bu ağır sorumluluklar ise zamanla annenin fizikselruhsal-sosyal uyumunun bozulmasına ve yaşam doyumunun azalmasına neden olmaktadır (Forinder 2004, Packman ve ark. 2010, Matteo ve Ceron 2015, Baran 2018).

Kanser tanısı olan bireye bakım verenlerde, yorgunluk, uykusuzluk, iştah ve kilo kab1 (Stenberg ve ark. 2010), baş, boyun, omuz sorunları, arterit, (Girgis ve ark. 2013), konsantrasyon bozukluğu, (Aranda ve Hayman-White 2001), ağır kaldırma nedeniyle bel ve ayak ağrısı (Gribich ve ark. 2001) gibi fiziksel semptomlar sık görülmektedir. Literatürde çocuğu kemik iliği nakli olan annelerle bu kapsamda yapılan bir araştırmaya rastlanmamasına rağmen, benzer semptomların yaşanacağı tahmin edilmektedir.

Anne çocuğun kemik iliği nakil sürecinde fiziksel olarak zorlanmanın yanı sıra duygusal olarak ta oldukça zor bir dönem geçirmektedir (Forinder 2004). Kendi varlığını çocuğu aracılığı ile sonsuzluğa taşımaya çalışan anne için çocuğun hastalanması büyük bir hayal kırıklığı oluşturmaktadır (Yalom 2008). Aynı zamanda annenin nakilin başarısız olması, hastalığın tekrarlaması, çocuğu kaybetme ve kayıptan sonra yaşamın nasıl devam edeceği gibi düşünceleri varoluşsal kaygılara ve ayrılık anksiyetesine neden olmaktadır (Forinder 2004, Vrijomoet-Wiersma ve ark. 2009).

Çocuğu kemik iliği nakli olmuş bir anne hastane sürecinde yaşadıklarını; "Doktor ve hemşire dört duvar arasında hep çocuk nasıl diyorlar, tabi olması gereken de bu ama anne olarak sende halin hatırın sorulsun istiyorsun, sıkıntılarını anlatacak birini arıyorsun. Herkes bana sen annesin sen güçlü olmalısın diyor...” şeklinde ifade etmiştir (Engin ve ark. 2019). Oppenheim ve ark.'nın (2002) yaptı̆̆ı araştırmada ise bir ebeveyn sağlık personelinin kendisini anlamasının mümkün olmadığını belirtmiştir (Oppenheim ve ark. 2002). Başka bir anne deneyimlerini, "Ben ve yakınlarım çok zorlu bir süreçten geçiyoruz. Mesela hasta odasından hiç çıkamama, geride bıraktıklarım, ailemiz... Omuzlarımda çok yük var, üstelik çocuğumun iyileşme göstermemesi çok sıkıntı yaratıyor. Çocuğum için nakil olacak tamamen iyileşecek diyordum... Ama hayat her zaman istediğimiz gibi gitmiyor. Çok kötü bir süreç geçiriyorum. Nakil tutmadı dediklerinde çok kötü oldum, saatlerce ağladım, her şeyden umudu kestim, kendimi öldürmeyi bile düşündüm. Öyle bir noktadasınız ki ümitler tükeniyor, bundan sonraki süreç beni çok korkuttu, kimseye anlatamadım yaşadıklarımı, anlatsam da anlamadılar zaten..." (Engin ve ark. 2019) şeklinde belirtmiştir.

Yukarıda yer alan ifadeler, çocuğun kemik iliği nakil sürecinde annelerin ruhsal desteğe ihtiyacı olduğunu açıkça göstermektedir. Literatürdeki verilerde bu ifadeleri destekler niteliktedir. Yapılan birçok araştırmada, çocuğu kemik iliği nakli olan annelerin yoğun stres yaşadığ1 ve anksiyete, depresyon, post travmatik stres bozukluğu gibi psikiyatrik hastalıkları 
deneyimlediği bildirilmektedir (Manne ve ark. 2001, Nelson ve ark. 2003, Manne ve ark. 2004, Phipps ve ark. 2004, Vrijomoet-Wiersma ve ark. 2009, Barrera ve Antenafu 2012, Virtue ve ark. 2014, Taşkıran ve ark. 2016). Ayrıca annenin genç yaşta olması, sosyal desteğinin olmaması, maddi gelirin düşük olması ve daha önceden ruhsal hastalığa sahip olması gibi etmenler, annede ruhsal hastalıkların görülme oranını artırmaktadır (Manne ve ark. 2001, Nelson ve ark. 2003).

Çocuğun kemik iliği nakil sürecinde annenin sosyal yaşamı da olumsuz etkilenmektedir. Anne, bakım verici rolü ile beraber uzun süre kendi kişisel ve sosyal aktivitelerine zaman ayıramamakta ve işinden ayrılmak ya da emekli olmak zorunda kalabilmektedir. Zamanla oluşan bu sosyal izolasyon ise anneyi yalnız hissettirmektedir. Annenin yalnızlık duygusu ile baş edebilmesi için yakın çevresinden ve sağlık personelinden destek görmesi oldukça önemlidir (Forinder 2004). Çünkü çocuğun nakil sürecinde destek görmeyen annelerde daha çok depresyon ve anksiyete bozukluğu yaşandiğı, sosyal uyumunun bozulduğu ve yaşam doyumunun azaldığı bildirilmektedir (Nelson ve ark. 2003, Baran 2018). Ayrıca çocuğun kemik iliğgi nakil sürecinde eşler arasındaki ilişki de zarar görebilmektedir. Bazı çiftler ayrılık kararı almalarına rağmen çocuğun hastalığı nedeniyle evliliklerini sürdürürken, bazıları boşanmaktadır (Forinder 2004, Çoban 2006). Örneğin çocuğu kemik iliği nakli olan bir anne, "Hastanede ben çocuğuma bakarken o beni aldattı, ondan nefret ediyorum..." (Engin ve ark. 2019) diyerek eşine olan kızgınlığını dile getirmiştir.

Çocuğu kemik iliği nakli olmuş annelerin yaşadığı bir diğer önemli sorun ise hastalık ve nakil süreci ile ilgili bilgi gereksinimlerinin karşılanmamı̧ olmasıdır. Yı1maz ve ark.'nın (2013) yaptığı araştırmada, çocuğu kemik iliği nakli olan annelerin bilgi gereksinimlerinin yüksek düzeyde olduğu; özellikle ilaçlar ve yan etkileri, diyare, bulant1, kusma, yorgunluk, ağr1 ve deri bakımı gibi konularda yüksek düzeyde bilgiye ihtiyaçları olduğu saptanmıştır (Y1lmaz ve ark. 2013). Mayer ve ark.'nın (2009) yaptığı araştırmada ise, çocuğu kemik iliği nakli olmuş ebeveynlerin büyük bir çoğunluğunun $(\% 81,5)$ bilgi kaynağ kullandıkları bildirmiştir. Bu sebeplerle ebeveynlerin, kemik iliği nakli hakkında alanında uzman kişiler tarafindan bilgilendirilmesi oldukça önemlidir (Mayer ve ark. 2009).

İnsan her zaman bilmediği ve kontrolü altına alamadığ 1 şeylerden daha çok korkmaktadır. Çocuğu kemik iliği nakli olan bir anne, hemşirenin nakil ve bakım ile ilgili ayrıntılı bilgilendirilmesinden sonra, "Çocuğuma nasıl daha iyi bakacağım konusunda bilgilenmem kendimi daha güçlü hissettirdi” yorumunda bulunmuştur (Engin ve ark. 2019)

Ayrıca ebeveynler zaman zaman kemik iliği nakline karar verdikleri için suçluluk duyabilmektedir. Çünkü nakil sürecinde zaman zaman çocuk fiziksel acı çekmekte, komplikasyonlar oluşabilmekte ve ölüm riski her zaman bulunmaktadır. Anne bu durumda çocuğuna en iyi bakımı vererek suçluluk duygusunu azaltmaya çalışabilir. Örneğin çocuğu kemik iliği nakli olan bir anne "Nakil sürecinde ve sonrasında neler yapacağımı anlamam vicdan azabımı azalttı” (Engin ve ark. 2019) yorumunda bulunmuştur.

Yukarıda belirtilen çok boyutlu sorunlar içerisinde belki de anneyi en çok zorlayan ve ruhsal acıya neden olan durum sürecin "belirsiz" olmasıdır. Matteo ve Ceron'nun (2015) yaptığı araştırmada çocuğu kemik iliği nakli olan bir anne, yaşadığı süreci "Gün gün, ay ay 
yaşıyorum... gelecekle ilgili plan yapmıyorum...”(Matteo ve Ceron 2015) şeklinde ifade etmiştir Yine aynı araştırmada başka bir anne çocuğun kemik iliği nakli sürecini "Bu durum sanki uçurumdan dönmek gibi bir şey” şeklinde tanımlamıştır. Zebrack ve ark.'nın (2002) yaptığ1 araştırmada çocuğu kanser tedavisi alan bir anne ise, "Kanser tedavisi patlamaya hazır bir bomba, ne zaman patlayacağını bilemezsin” (Zebrack ve ark. 2002) yorumunda bulunmuştur. Katlanılması oldukça zor olan belirsizlik, bireysel algı ile yetersizlik ve dayanıksızlık düşüncesine; kaygı, korku, öfke, çaresizlik, suçluluk gibi duygulara ve depresyon, anksiyete bozukluğu gibi psikiyatrik hastalıklara neden olmaktadır (Öz 2001, Oppenheim ve ark. 2002, Asadi ve ark. 2011, Geçkin ve Sahranç 2017).

Çocuğu kemik iliği nakli olan annelerde psikiyatrik semptom ve hastalıklar oldukça sık görülmesine rağmen literatürde annelerin sorularına yönelik girişimsel araştırmalar oldukça sınırlı sayıdadır. Streisand ve ark.'nın (2000) yaptığı araştırmada, eğitim, relaksasyon ve iletişim becerilerinden oluşan girişimin, çocuğu kemik iliği nakli olmuş ebeveynlerin yaşadığı stresi azaltmada etkili olduğu bildirilmiştir (Streisand ve ark. 2000). Manne ve ark.'nın (2016) çocuğu kemik iliği nakli olan ebeveynlerle yürüttükleri randomize kontrollü araştırmada ise uygulanan girişim (bilgilendirme, duyguların tartışılması, problem çözme, nefes egzersizleri, imajinasyon, progresif gevşeme, sosyal uyum vb.) deney grubunun stres düzeyini azaltmada etkili olmuştur (Manne ve ark. 2016). Ulusal literatür incelendiğinde ise kemik iliği nakli olmuş bireylerin bakım vericilerinin ihtiyaçlarını saptamaya yönelik sınırlı sayıda araştırmanın yapıldığı görülmüş(Aslan ve ark. 2006, Y1lmaz ve ark. 2013) ve mevcut sorunları çözmeye yönelik girişimlere rastlanmamıştır.

\section{Çocuğun kemik iliği nakil sürecinde KLP hemşiresinin rolü}

KLP hemşiresi, fiziksel yakınması ya da hastalığı olan bireyin ve ailesinin, fiziksel, ruhsal ve psikososyal bakımından sorumludur. Sağlık hizmetlerinin koordinasyonu, hemşirelerin gelişimi ve alana katkı sağlayacak bilimsel faaliyetlerin yürütülmesi diğer sorumlulukları arasındadır. KLP hemşiresi bu sorumlulukları yerine getirirken başlıca klinik (konsültasyon ve liyezon), eğitim, araştırma ve yönetim rollerini kullanmaktadır (Kocaman 2005, Çam ve Engin 2014).

KLP hemşiresi çocuğun kemik iliği nakil sürecinde anneye destek sağlanmasında merkezi bir role sahiptir. Çocuğun kemik iliği nakli olması annenin hayatındaki önemli dönüm noktalarından biridir. Çoğu anne bu dönemde durumsal bir kriz yaşamaktadır. Bu nedenle KLP hemşiresinin çocuk ve aile için durumsal kriz değerlendirmesi yapması yararlı olacaktır. Bazı ebeveynler çocuğun kemik iliği nakli sürecinde baş edebilmek için inkâr savunma mekanizmasını kullanabilmektedir. Bazı ebeveynler ise suçluluk duygusu ve endişe nedeniyle düşüncelerini ve duygularını kendilerine bile yüksek sesle ifade edememektedir. Süreci tam olarak kabullenmeden tedaviye başlayan ebeveynlerde ise korku daha yoğun yaşanabilir (Forinder 2004). KLP hemşiresi mesleki becerileri kullanarak öncelikle annenin duygu ve düşünlerini paylaşmasına, durumu anlamasına ve kabullenmesine yardımcı olmalıdır (Forinder 2004, Kocaman 2005, Çam ve Engin 2014, Matteo ve Ceron 2015).

KLP hemşiresi anneye her zaman dürüst davranmalı ve açık iletişim kurmalıdır. 
Çünkü ebeveynler bazen sağlık ekibine karşı ambivalan duygular besleyebilmektedir. Oppenheim ve ark.'nın (2002) yaptığı araştırmada bir anne, sağlık personeline karşı olan düşüncelerini şu şekilde ifade etmiştir "Kızımı öldürebilirler ya da iyileştirebilirler" (Oppenheim ve ark. 2002). Ayrıca bazı ebeveynler kemik iliği nakli ve süreci ile ilgili sağl1k profesyonelleri tarafından yeterince bilgilendirilmediklerini düşünmektedir (Asadi ve ark. 2011). Bu durum ebeveynlerin sağlık ekibine karşı öfke duymasına ve kendilerini yalnız hissetmelerine neden olabilir. Bu sebeple KLP hemşiresi hemşire ve anne arasında köprü vazifesi görmelidir. KLP hemşiresi tarafından her iki tarafında düşüncelerinin ve duygularının anlaşılması gerekmektedir. Zaman zaman kemik iliği nakil ünitelerinde çalışan hemşireler hasta yakınlarının duygu ve düşüncelerini anlamakta zorlanabilirler. $\mathrm{Bu}$ ünitelerde çalışan hemşirelerde, ölümle yüz yüze olma (özellikle ölenin kişinin çocuk olması), uzun çalışma saatleri, işe bağlı stres, iş yükü gibi birçok sebeple tükenmişlik, depersonalizasyon, yorgunluk gibi semptomlar görülebilmekte ve anksiyete, depresyon gibi ruhsal hastalıklar oluşabilmektedir. Bu sebeple KLP hemşiresi kemik iliği nakil ünitelerinde çalışan hemşirelere, ruhsal destek için psikoeğitim ve psikoterapi uygulamaları yapması, hemşirelerin ruhsal sağlı̆̆ının korunmasına, çocuğa ve hasta yakınan verilen bakımın kalitesinin artmasına yardımcı olacaktır (Kocaman 2005, Gallagher ve Gormley 2009, Morrison ve Morris 2017).

KLP hemşiresinin önemli sorumluluklarından bir diğeri ise çocuğu kemik iliği nakli olan annelere psikoeğitim vermektir. İhtiyaçlara yönelik olarak verilen psikoeğitimler, annenin kendi duygu ve düşüncelerine farkındalık kazanmasına, kullanılan adaptif ve maladaptif baş etme yöntemlerinin belirlenmesine, stres, anksiyete ve öfke yönetimine, güçlü yönlerin farkına varılmasına, çocuğun bakımı ile ilgili bilgi düzeyinin ve öz güvenin artmasına, sağlıklı kişiler arası ilişkiler sürdürülmesine ve annenin çocuğuna verdiği bakımın kalitesinin artmasına katkı sağlayacaktır (Öz 2001, Zebrack ve ark. 2002, Forinder 2004, Kocaman 2005, Çam ve Engin 2014, Manne ve ark. 2016, Matteo ve Ceron 2015, Engin ve ark. 2019).

Çocuğu kemik iliği nakli olan annelere KLP hemşiresi tarafından psikoterapi uygulamalarının yapılması önemli bir gerekliliktir. Çünkü birçok ebeveyn kemik iliği nakil sürecinde, çocuktaki fiziksel değişimler nedeniyle, çocuğunu yavaş yavaş kaybettiğini düşünerek yoğun ruhsal acı yaşayabilmektedir (Oppenheim ve ark. 2002). Psikoterapi uygulamaları ile beraber anne "şimdi ve buradaya" çekilebilir. Kemik iliği nakli sürecinde genellikle annenin zihni geleceğe yönelik kaygı verici düşüncelerle meşguldür. Bu düşünceler annenin çocuğunun o an yanında olduğunun farkına varmasını engelleyebilir. KLP hemşiresi annenin o an da kalmasını sağlayarak, anne ve çocuk arasında hastane ortamında olunmasına rağmen, yeni anılar oluşmasına yardımcı olabilir. Ayrıca o anda kalarak annenin çocuğuyla vakit geçirmesini sağlamak annenin psikolojik dayanıklılığının ve belirsizliğe tahammülünün artmasına katkı sağlayabilir (Kars 2011).

KLP hemşiresi çocuğun kemik iliği nakli sürecinde annenin olayı normalleştirmesine yardımcı olmalıdır.Annenin, kemik iliği naklinin birçok insan tarafından yaşanan ortak bir deneyim olduğunun farkına varması normalleşme sürecine katkı sağlayacaktır. Anne olağanüstü bir şey yaşıyorum düşüncesinden uzaklaşıp çocuğun kemik iliği naklini ne kadar 
normalleştirebilirse yaşanan akut krizi de o kadar iyi yönetecektir (Forinder 2004). Ayrıca olayın normalleştirilerek bilişsel olarak kontrol altına alınması, kemik iliği naklinin travmaya neden olmadan yaşam öyküsüne dahil edilebilmesini mümkün kilabilir (Forinder 2004, Calhoun ve Tedeschi 2006, Yalom 2008, Asadi ve ark. 2011).

Yukarıda belirtilen tüm girişimlere ek olarak KLP hemşiresini benzer deneyimleri yaşayan aileleri bir araya getirerek grup terapisi yapabilir. Bu etkileşim annenin kemik iliği naklini bilişsel yapısı içerisinde normalleştirmesine, acının evrenselliğini anlamasına ve umudunu korumasına da yardımcı olabilir. Çünkü çocuğu kemik iliği nakli olan bazı anneler umutlarını korumakta ve kemik iliği naklini yeni bir yaşam başlangıcı olarak değerlendirmektedir (Oppenheim ve ark. 2002, Asadi ve ark. 2011). Aynı zamanda bazı anneler travma sonrası büyümede yaşamaktadır. Literatürde oldukça az sayıda araştırma yapılmasına rağmen, çocuğun kemik iliği nakli sürecinde bazı annelerin güçlendiği, daha yakın kişiler arası ilişkiler kurduğu ve yaşama karşı daha fazla şükran duyduğu bildirilmektedir (Matteo ve Ceron 2015, Forinder ve Norberg 2014). Ek olarak kemik iliği nâkilini, yaşam ve sağlığın kıymetini anlamak için bir firsat olarak değerlendiren annelerde bulunmaktadır (Asadi ve ark. 2011). Bu olumlu deneyimlerin ve düşüncelerin karşılıklı paylaşılmasının ise, annelerin acıyı anlamlandırmasına ve kabulüne katkı sağlayacağı düşünülmektedir.

\section{Sonuç}

Bu derleme, çocuğu kemik iliği nakli olmuş annelerin yaşadığı sorunları ve bu süreçte KLP hemşiresinin rollerini açıklamak/tanımlamak amacıyla yazılmıştır. Literatürde yapılan birçok araştırma, çocuğun kemik iliği sürecinde annenin duygusal zorluklar yaşadığını ve KLP hemşiresi tarafından verilecek bakıma ihtiyaç duyduğunu açıkça göstermektedir. Tüm dünyada ve ülkemizde bu spesifik alana özgü yetkin KLP hemşirelerin yetiştirilmesine özel ihtiyaç bulunmaktadır. KLP hemşireliği lisansüstü eğitim programlarının açılmasının ve kemik iliği nakil hemşireliğine özgü psikoeğitim, çalıştay, workshop ve kongrelerin düzenlenmesinin bu ihtiyacın giderilmesine önemli katkı sağlayacağı düşünülmektedir.

\section{Kaynaklar}

Açar A (2005) Organ transplantasyonu yapılan çocukların ebeveynlerinin yaşam kalitesi ve bakım yükünün belirlenmesi (Yüksek lisans tezi). Urfa, Harran Üniversitesi.

Adanır AS, Taşkıran G, Küpesiz OA, Özatalay E. Psychopathology in pediatric bone marrow transplantation survivors and their mothers. Pediatr Int, 2017;59:979-985.

Aranda SK, Hayman-White K (2001) Home caregivers of the person with advanced cancer. Cancer Nurs, 24:300-306.

Asadi M, Manookian A, Nasarabadi AN (2011) Parents' experiences of their childeren bone marrow transplantation: a qualitative study. Int J Hematol Oncol Stem Cell Res, 5:1-7.

Aslan Ö, Kav S, Meral C, Tekin F, Yeşil H, Öztürk U et al. (2006) Needs of lay caregivers of bone marrow transplant patients in Turkey. Cancer Nurs, 29:1-7.

Baran G (2018) The burden of care and life satisfaction of the Turkish mothers of children with cancer. Journal of Client-Centered Nursing Care, 4:175-184.

Barrera M, Atenafu E, Doyle J, Berlin-Romalis D, Hancock K (2012) Differences in mothers' and fathers' psychological distress after pediatric SCT: a longitudinal study. Bone Marrow Transplant, 47:934-939.

Calhoun LG, Tedeschi RG (2006) The foundations of posttraumatic growth: An expanded framework. In The Handbook of Posttraumatic 
Growth: Research and Practice (Eds LG Calhoun, RG Tedeschi):1-23. Mahwah, Lawrence Erlbaum Associates.

Çam 0, Engin E (2014) Ruh Sağlığı ve Hastalııları Hemşireliği: Bakım Sanatı. İstanbul, İstanbul Tıp Kitabevi.

Çoban ÖG (2016) Kemik iliği nakli olan çocukların sağlıklı kardeşlerinde psikopatoloji, yaşam kalitesi, travma sonrası stres bozukluğu ve davranış problemlerinin değerlendirilmesi (Uzmanlık Tezi). Antalya, Akdeniz Üniversitesi.

Engin E, Çam 0, Demirkol H, Doğan EÖ (2019) The effect of psychoeducation on care burden applied to mothers of children underwent bone marrow transplantation. İzmir, Ege University Scientific Research Projects Coordination, 16-HY0-002.

Er M (2006) Çocuk, hastalık, anne-babalar ve kardeşler. Çocuk Sağlığı ve Hastalıkları Dergisi, 49:155-168.

Ersoy E (2009) Cinsiyet kültürü içerisinde kadın ve erkek kimliği (Malatya Örneği). Frrat Üniversitesi Sosyal Bilimler Dergisi, 19:209230.

Forinder U (2004) Bone marrow transplantation from a parental perspective. J Child Health Care, 8:134-148.

Forinder U, Norberg AL (2014) Posttraumatic growth and support among parents whose children have survived stem cell transplantation. J Child Health Care, 18:326-335.

Gallagher R, Gormley DK (2009) Perceptions of stress, burnout, and support systems in pediatric bone marrow transplantation nursing. Clin J Oncol Nurs, 13:681-685.

Geçgin FM, Sahranç Ü (2017) Belirsizliğe tahammülsüzlük ile psikolojik iyi oluş arasındaki ilişki. Sakarya University Journal of Education, 7:739-755.

Girgis A, Lambert S, Johnson C, Waller A, Currow D (2013) Psysical, psychosocial, relationship, and economic burden of caring for people with cancer. J Child Health Care, 9:197-202.

Gribich CF, Maddocks I, Parker D (2001) Family caregivers, their needs, and home based palliative care services. J Fam Health, 7:171188.

Kars MC, Grypdonck MH, van Delden JJ (2011) Being a parent of a child with cancer throughout the endof-life course. Oncol Nurs Forum, 38:260-271.

Koca E, Akpek G (2006) Graft-versus-host hastalığı ve tedavi yöntemleri. Türkiye Klinikleri Dahili Tip Bilimleri Dergisi, 2(19):23-32.

Kocaman N (2005) Konsültasyon liyezon psikiyatrisi hemşireliği ve rolü nedir? Anadolu Hemşirelik ve Sağık Bilimleri Dergisi,8:107-118.

Korucu AA (2019) Freudyen ve Jungiyen yaklaşımlarla anne olgusu. Atatürk Üniversitesi Sosyal Bilimler Enstitüsü Dergisi, 23:133-143.

Manne S, Bartell A, Mee L, Snds S, Kasy DA (2016) A randomized clinical trial of a parent focus social-cognitive processing intervention for caregivers of children undergoing hematopoetic stem call transplantation. J. Consult Clin Psychol, 84:389-401.

Manne S, DuHamel K, Ostroff J, Parsons S, Martini RD, Williams ES et al. (2004) Anxiety, depressive, and post traumaticstress disorder among mothers of pediatric survivor of hematopoietic stem cell transplantation. Pediatrics,113:1700-1707.

Manne S, Ostroff J, Mertini R, Sexson S, Mee L, DuHamel K (2001) Anxiety and depression in mothers of children undergoing bone marrow transplant: syptom prevalence and use of the beck depression and beck anxiety inventories as screening instruments. J Consult Clin Psychol, 69:1037-1047.

Matteo B, Ceron M (2015) Uncertainty in pediatric bone marrow transplantation: a qualitative analysis about parents' perspective. Nurse Educ Pract, 6:111-117.

Mayer DK, Tighiouart H, Terrin N, Stewart S, Peterson E, Jeruss S et al. (2009) A brief report of caregiver needs and resource utilization during pediatric hematopoietic stem cell transplantation. J Pediatr Oncol Nurs, 26:223-229.

Morrison CF, Morris EJ (2017) The Practices and meanings of care for nurses working on a pediatric bone marrow transplant unit. J Pediatr Oncol Nurs, 34:214-221.

Nelson EA, Gleaves L, Nuss S (2003) Mothers's responses during child's stem cell transplantation: pilot study. J Pediatr Nurs, 29:219223.

Oppenheim D, Valteau-Couanet D, Vasselon S, Hartmann 0 (2002) How do parents perceive high-dose chemotherapy and autologous stem cell transplantation for their children. Bone Marrow Transplant, 30:35-39.

Önen Ş̧̧ (2014) Kemik iliği nakli yapılmış yaşayan çocuklarda solunum ve dolaşım komplikasyonlarının erken ve geç dönem değerlendirilmesi (Uzmanlık tezi). İzmir, Ege Üniversitesi.

Öz F (2001) Hastalık yaşantısında belirsizlik. Turk Psikiyatri Derg, 12:61-68.

Packman W, Weber S, Wallace J, Bugescu N (2010) Psychological effects of hematopoietic SCT on pediatric patients, siblings and parents: a review. Bone Marrow Transplant, 45:1134-1146.

Peykerli G (2003) Kemik iliği naklinin psikososyal boyutu. Türkiye Klinikleri J Hematol, 1:134-137. 
Phipps S, Dunavant M, Lensing S, Rai SN (2004) Patterns of distress in parents of children undergoing stem cell transplantation. Pediatr Blood Cancer, 43:267-274.

Prinds C, Mogensen 0, Hvidt NC, Bliddal M (2018) First child's impact on parental relationship: an existential perspective. BMC Pregnancy Childbirth, 18:157.

Streisand R, Rodrigue JR, Houck C, Graham-Pole J, Berlant N (2000) Brief report: paterns of children undergoing bone marrow tranplantation: documenting stress and piloting a psycological intervention program. J Pediatr Psychol, 25:331-337.

Tanzi EM (2011) Health-related quality of life of hematopoietic stem cell transplant childhood survivors: state of the science. J Pediatr Oncol Nurs, 28:191-202.

Taşkıran G, Adanır AS. Özatalay S (2016) Living with the unknomn: posttraumatic stress disorder in pediatric bone marrow transplantation survivors and their mother. J Pediatr Hematol Oncol,33:209-218.

Tura SM (2005). Freud'dan Lacan'a Psikanaliz. İstanbul, Kanat Kitap.

Virtue MS, Manne SL, Mee L, Bartell A, Sands S, Gajda TM et al. (2014) Psychological distress and psychiatric diagnoses among primary caregivers of children undergoing hematopoietic stem cell transplant: an examination of prevalence, correlates, and racial/ethnic differences. Gen Hosp Psychiatry, 36:620-626.

Vrijmoet-Wiersma CMJ, Egeler RM, Koopman HM, Norberg AL, Grootenhuis MA (2009) Parental stress before, during, and after pediatric stem cell tranplantation: a review article. Support Care Cancer, 17:1435-1443.

Yabroff KM, Kim Y (2009) Time costs associated with informal caregiver for cancer survivors. Cancer, 115:4362-4373.

Yalom I (2008) Güneşe Bakmak Ölümle Yüzleşmek (Çeviri Ed. Z İyidoğan Babayiğit). İstanbul, Kabalcı Yayınevi.

Yeşilipek MA (2014) Çocuklarda hematopoetik kök hücre nakli. Turk Pediatri Ars, 49:91-98.

Yılmaz MC, Aksoylar S, Kansoy S (2013) The informational needs of mothers about physical care at home for children who underwent stem cell transplants. Int J Caring Sci, 6:106-113.

Zebrack B, Chesler M, Orbuch TL, Parr C (2002) Mothers of survivors of childhood cancer: their worries and concerns. J Psychosoc Oncol, 20:1-25.

Yazarların Katkıları: Yazarlar çalışmaya önemli bir bilimsel katkı sağladıklarını ve makalenin hazırlanmasında veya gözden geçirilmesinde yardımcı olduklarını kabul etmişlerdir.

Danışman Değerlendirmesi: Dış bağımsız.

Çıkar Çatışması: Yazarlar çıkar çatışması bildirmemiştir.

Finansal Destek: Yazarlar bu çalışma için finansal destek almadıklarını beyan etmişlerdir.

Authors Contributions: The authors attest that they made an important scientific contribution to the study and have assisted with the drafting or revising of the manuscript.

Peer-review: Externally peer-reviewed.

Conflict of Interest: No conflict of interest was declared by the authors.

Financial Disclosure: The authors declared that this study has received no financial support. 